\title{
THE OXYGEN TENSION OF THE BLOOD IN THE UMBILICAL CORD AND THE INTERVILLOUS SPACE
}

\author{
BY \\ S. SJÖSTEDT, G. ROOTH and F. CALIGARA \\ From the Departments of Obstetrics and Gynaecology and Internal Medicine, University Hospital, Lund, \\ and the Wenner-Gren Cardiovascular Research Laboratory, Norrtull Hospital, Stockholm, Sweden
}

(RECEIVED FOR PUBLICATION APRIL 19, 1960)

During recent years there has been a revival of the interest in oxygen saturation in the umbilical blood; this work was started in the 1930's by Haselhorst and Stromberger (1931) and several papers have been published by different groups (Walker and Turnbull, 1953; MacKinney, Ehrlich, Goldberg and Cantwell, 1955; Rooth and Sjöstedt, 1955, 1957; Bancroft-Livingston and Neill, 1957; Turnbull and Baird, 1957). It should be remembered, however, that measurements of oxygen saturation mainly give an indication of the amount of oxygen present in the blood. For a more complete picture of the oxygenation it is also necessary to know the oxygen tension $\left(\mathrm{pO}_{2}\right)$ since that is the force by which oxygen is pressed from the vessels into the tissues and because the physiological effect of the oxygen depends solely on its $\mathrm{pO}_{2}$.

As oxygen in foetal circulation is obtained from maternal blood in the intervillous space of the placenta, a comparison between the levels of $\mathrm{pO}_{2}$ in the intervillous space and in the umbilical vessels will indicate the diffusion pressure drop of the oxygen between the maternal and foetal circulation in the placenta.

\section{Material and Methods}

The cord blood was investigated in 178 cases after spontaneous delivery in vertex presentation. One hundred and twenty-eight of the infants were normal without any signs of asphyxia; 30 infants had signs of mild asphyxia, usually with slow or irregular heart beats. Nineteen infants had meconium stained amniotic fluid without any other signs of asphyxia.

During labour the mothers were given 'trilene' or nitrous oxide and in some cases a few drops of chloroform at the moment of delivery.

The cord was clamped immediately after birth and blood was drawn from the vein and the arteries into heparinized syringes. The analyses of the blood were started immediately.

The blood in the intervillous space was investigated in 25 cases of normal pregnancy. The placenta was punctured through the abdominal wall before labour had started. Only local anaesthesia was used and no complications occurred. Before puncture the placenta was localized as carefully as possible by palpation and auscultation (Norman, 1953) or sometimes by radiographs. The puncture was always made below the umbilicus on the side of the legs of the foetus. When the placenta was punctured, it was an easy matter to get $10-20 \mathrm{ml}$. of maternal blood into a heparinized syringe; if the uterine wall only was punctured the outcome was a few millilitres of blood obtained with difficulty. Punctures of the human placenta have also been made by Walker and Turnbull (1959) and Prystowsky (1959).

The $\mathrm{pO}_{2}$ was measured polarographically with the Clark electrode as described by us (Rooth, Sjöstedt and Caligara, 1959). Within the range of $\mathrm{pO}_{2}$ observed here, the error of the analyses should be less than $\pm 1 \mathrm{~mm}$. Hg.

Great care was taken in order to obtain as reliable information as possible about the time of gestation. Most of the mothers were under observation by the staff during pregnancy and any case in which the duration of pregnancy was doubtful was rejected from the investigation.

\section{Results}

The $\mathrm{pO}_{2}$ values from the vein are given in Fig. 1 and from the arteries in Fig. 2. In normal cases two-thirds of the observations from the vein are between 25 and $35 \mathrm{~mm}$. $\mathrm{Hg}$; in the arteries twothirds of the values are between 10 and $20 \mathrm{~mm}$. $\mathrm{Hg}$. The mean $\mathrm{pO}_{2}$ in normal cases is 29.3 in the vein and $18.3 \mathrm{~mm}$. $\mathrm{Hg}$ in the arteries.

Figs. 1 and 2 also give the $\mathrm{pO}_{2}$ values for the asphyxiated infants and infants with meconium stained amniotic fluid. The mean $\mathrm{pO}_{2}$ in the vein of the asphyxiated infants is $27 \cdot 0$ and in the arteries $16.0 \mathrm{~mm}$. $\mathrm{Hg}$. The mean $\mathrm{pO}_{2}$ in the vein of the infants with meconium stained amniotic fluid is 29.2 and in the arteries $15.6 \mathrm{~mm}$. $\mathrm{Hg}$.

In Table 1 the $\mathrm{pO}_{2}$ in 113 specimens from the umbilical vein and 89 samples from the arteries are divided according to gestation time. The 
VE IN
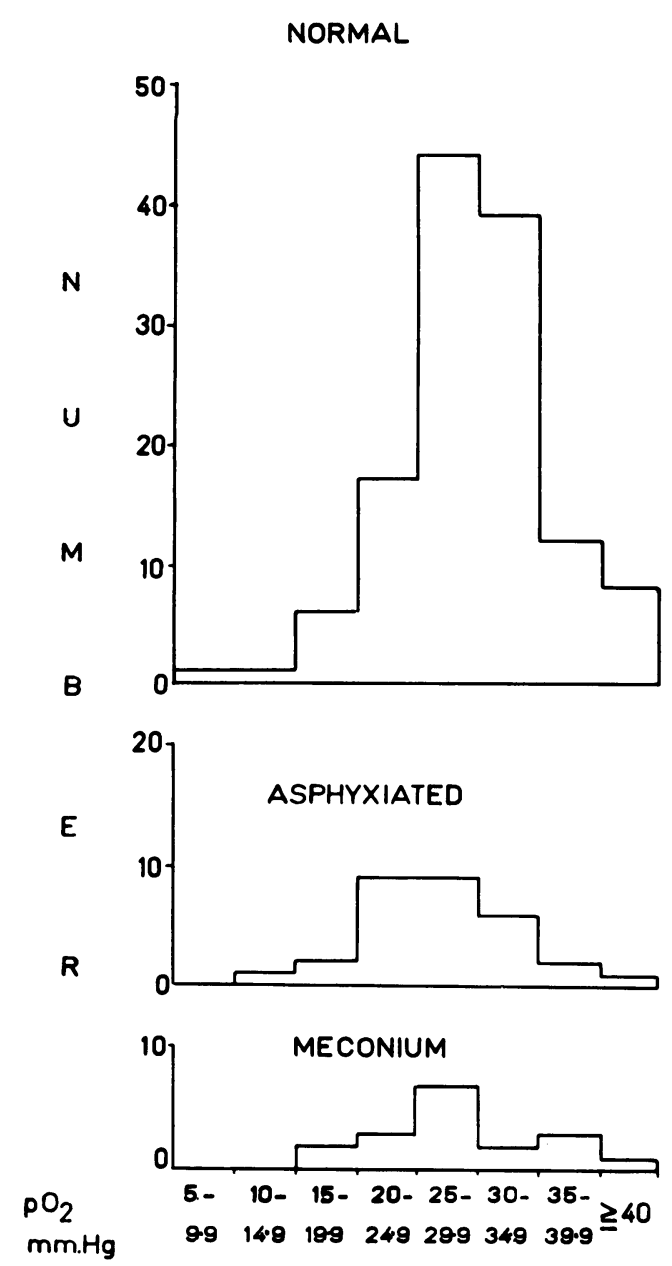

FIG. 1.-Distribution of the oxygen tension in the umbilical vein in normal and asphyxiated infants and infants with meconium stained amniotic fluid.

differences between the different weeks are small and irregular in the whole group as well as in the primigravidae (Table 2).

The results of the analyses of the intervillous blood are shown in Fig. 3. The mean $\mathrm{pO}_{2}$ is 39.9 $\mathrm{mm}$. $\mathrm{Hg}$ with the range 27.5 to $53.7 \mathrm{~mm}$. $\mathrm{Hg}$.

\section{Discussion}

The figures available in the literature on the $\mathrm{pO}_{2}$ of the cord blood are summarized in Table 3 . Direct measurements have been made by Beer,
ARTERIES
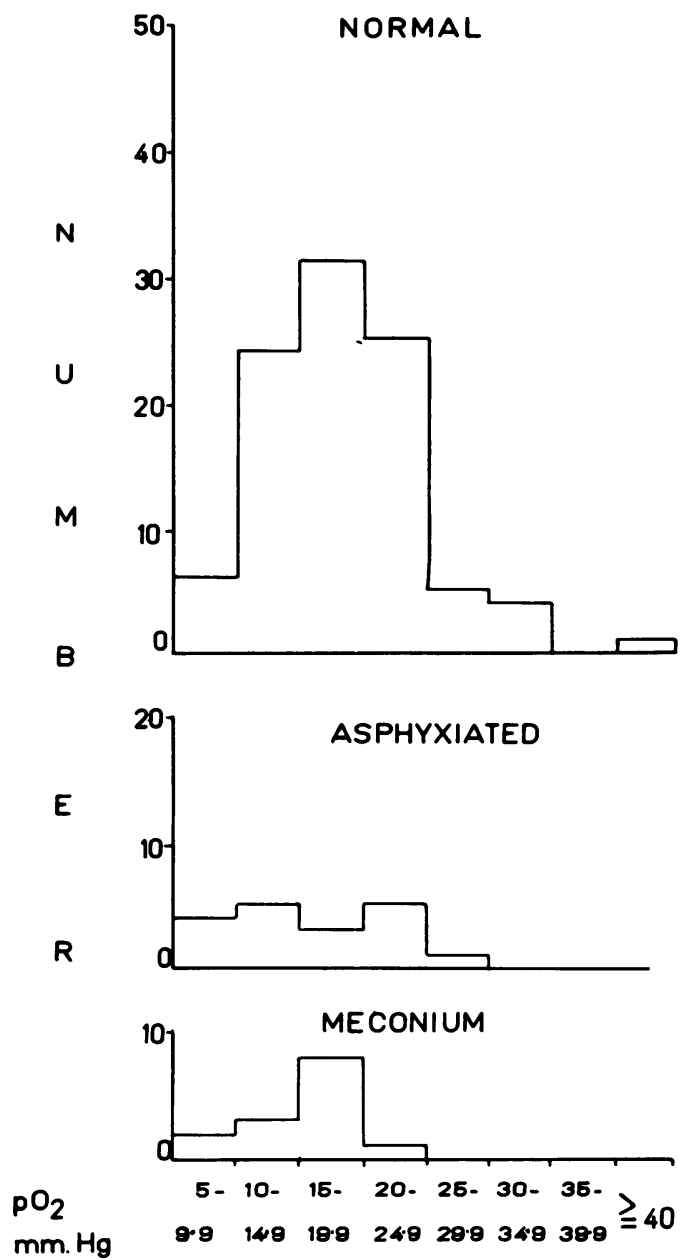

FIG. 2.-Distribution of the oxygen tension in the umbilical arteries in normal and asphyxiated infants and infants with meconium stained amniotic fluid.

Bartels and Raczkowski (1955), Wulf (1958) and Sjöstedt, Rooth and Caligara (1960). Beer et al. (1955) and Wulf used the potentiometric method of Bartels (1951). The mean values of Beer et al. are lower than might be expected from the oxygen saturation analyses cited above. They are difficult to explain and may be due to the individual cases. On the other hand the values given by Wulf correspond to ours and to the majority of the oxygen saturation measurements in the literature and it may therefore be assumed that the mean $\mathrm{pO}_{2}$ in the umbilical vein in normal cases is about $30 \mathrm{~mm}$. $\mathrm{Hg}$ 
TABLE 1

OXYGEN TENSION IN THE UMBILICAL CORD BLOOD AFTER NORMAL DELIVERY AT DIFFERENT GESTATION WEEKS

\begin{tabular}{|c|c|c|c|c|c|}
\hline \multirow{2}{*}{$\begin{array}{c}\text { Ges- } \\
\text { tation } \\
\text { (weeks) }\end{array}$} & \multicolumn{2}{|c|}{ Vein } & \multicolumn{2}{|c|}{ Artery } & \multirow{2}{*}{$\begin{array}{c}\text { Arterio- } \\
\text { venous } \\
\text { Difference }\end{array}$} \\
\hline & Number & $\begin{array}{l}\text { Mean pO2 } \\
(\mathrm{mm} . \mathrm{Hg})\end{array}$ & Number & $\begin{array}{l}\text { Mean pOs } \\
(\mathrm{mm} . \mathrm{Hg})\end{array}$ & \\
\hline $\begin{array}{l}38 \\
39 \\
40 \\
41 \\
42 \\
43\end{array}$ & $\begin{array}{r}4 \\
18 \\
36 \\
25 \\
18 \\
12\end{array}$ & $\begin{array}{l}31 \cdot 8 \\
28 \cdot 5 \\
28 \cdot 5 \\
31 \cdot 2 \\
29 \cdot 6 \\
28 \cdot 2\end{array}$ & $\begin{array}{r}3 \\
12 \\
30 \\
18 \\
15 \\
11\end{array}$ & $\begin{array}{l}21 \cdot 8 \\
19.9 \\
18 \cdot 0 \\
17 \cdot 5 \\
19 \cdot 3 \\
16 \cdot 0\end{array}$ & $\begin{array}{r}10 \cdot 0 \\
8 \cdot 6 \\
10 \cdot 5 \\
13 \cdot 7 \\
10 \cdot 3 \\
12 \cdot 2\end{array}$ \\
\hline Total $\ldots$ & 113 & $29 \cdot 3$ & 89 & $18 \cdot 2$ & $11 \cdot 1$ \\
\hline
\end{tabular}

at the time of delivery and the corresponding value in the arteries is about $18 \mathrm{~mm}$. $\mathrm{Hg}$.

Wulf shows, as expected, that the $\mathrm{pO}_{2}$ in the cord blood is less in the asphyxiated cases. In the present series the mean difference between the normal cases and both the asphyxiated group and the meconium group is small, but as shown in Figs. 1 and 2 there are more low values in the two latter groups than in the normal cases. In the normal

TABLE 2

OXYGEN TENSION IN THE UMBILICAL CORD BLOOD OF PRIMIGRAVIDAE AFTER NORMAL DELIVERY IN DIFFERENT GESTATION WEEKS

\begin{tabular}{|c|c|c|c|c|}
\hline \multirow{2}{*}{$\begin{array}{l}\text { Gestation } \\
\text { (weeks) }\end{array}$} & \multicolumn{2}{|c|}{ Vein } & \multicolumn{2}{|c|}{ Artery } \\
\hline & Number & $\begin{array}{l}\text { Mean pO } \\
(\mathrm{mm} \text {. Hg) }\end{array}$ & Number & $\begin{array}{l}\text { Mean } \mathrm{pO}_{2} \\
(\mathrm{~mm} . \mathrm{Hg})\end{array}$ \\
\hline $\begin{array}{l}38 \\
39 \\
40 \\
41 \\
42 \\
43\end{array}$ & $\begin{array}{r}2 \\
13 \\
17 \\
6 \\
8 \\
8\end{array}$ & $\begin{array}{l}30 \cdot 8 \\
29 \cdot 2 \\
28 \cdot 0 \\
30 \cdot 8 \\
33 \cdot 7 \\
29 \cdot 2\end{array}$ & $\begin{array}{r}2 \\
10 \\
14 \\
6 \\
7 \\
6\end{array}$ & $\begin{array}{r}9 \cdot 1 \\
20.9 \\
17.6 \\
20.6 \\
25.2 \\
18.2\end{array}$ \\
\hline Total & 54 & $29 \cdot 7$ & 45 & $19 \cdot 9$ \\
\hline
\end{tabular}

cases there are $19 \%$ with a $\mathrm{pO}_{2}$ in the vein of less than $25 \mathrm{~mm}$. $\mathrm{Hg}$, while in the meconium group there are $32 \%$ and in the asphyxiated group $40 \%$. The corresponding frequency of values less than $15 \mathrm{~mm}$. $\mathrm{Hg}$ in the arteries is 31,36 and $50 \%$.

Just as was found in our study on the oxygen saturation in the cord blood (Rooth and Sjöstedt, 1955), the group labelled 'asphyxiated' contains some cases with normal and others with lowered $\mathrm{pO}_{2}$. This is explained by the fact that most of our cases of asphyxia only manifested themselves temporarily in the form of foetal bradycardia before birth.

In comparing the values between the normal and the asphyxiated cases it can be seen that the differences are much smaller for the $\mathrm{pO}_{2}$ than they are for the oxygen saturation. This is because of the shape of the oxygen dissociation curve. In measurements of adult arterial blood the oxygen saturation may vary from between 92 to $96 \%$, whereas at the same time the $\mathrm{pO}_{2}$ changes from 70 to $95 \mathrm{~mm}$. $\mathrm{Hg}$. This is because the values lie in the horizontal range of the oxygen dissociation

TABLE 3

SURVEY OF UMBILICAL CORD BLOOD $\mathrm{pO}_{2}$ STUDIES

\begin{tabular}{|c|c|c|c|c|}
\hline \multirow{2}{*}{ Author } & \multicolumn{2}{|c|}{ Artery } & \multicolumn{2}{|c|}{ Vein } \\
\hline & Number & Mean $\mathrm{pO}_{2}$ & Number & Mean $\mathrm{pO}_{2}$ \\
\hline 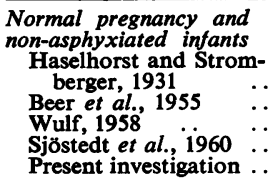 & $\begin{array}{l}22 \\
36 \\
51 \\
96\end{array}$ & $\begin{array}{r}9 \cdot 2 \\
15 \cdot 7 \\
16 \cdot 9 \\
18 \cdot 3\end{array}$ & $\begin{array}{r}4 \\
24 \\
36 \\
68 \\
128\end{array}$ & $\begin{array}{l}31 \cdot 0 \\
22 \cdot 4 \\
32 \cdot 0 \\
28 \cdot 9 \\
29 \cdot 3\end{array}$ \\
\hline $\begin{array}{l}\text { Asphyxiated infants } \\
\text { Wulf, 1958 } \\
\text { Present investigation . . }\end{array}$ & $\begin{array}{l}20 \\
32\end{array}$ & $\begin{array}{r}4 \cdot 0 \\
15 \cdot 8\end{array}$ & $\begin{array}{l}20 \\
49\end{array}$ & $\begin{array}{r}7 \cdot 3 \\
27 \cdot 9\end{array}$ \\
\hline
\end{tabular}

curve. With the umbilical blood the opposite occurs. The values are now in the range of the vertical part of the dissociation curve and although the oxygen saturation changes from 70 to $45 \%$ the tension only decreases from 30 to $25 \mathrm{~mm}$. $\mathrm{Hg}$. In this way the already initially low $\mathrm{pO}_{2}$ is maintained, although the oxygen supply is reduced. This has been called the buffering effect of the curve (Barron, 1959).

Most obstetricians associate the presence of meconium staining of the amniotic fluid with intrauterine hypoxia. The present series substantiates this in so far as the $\mathrm{pO}_{2}$ in the cord blood is low more often in the meconium group than in the normal.

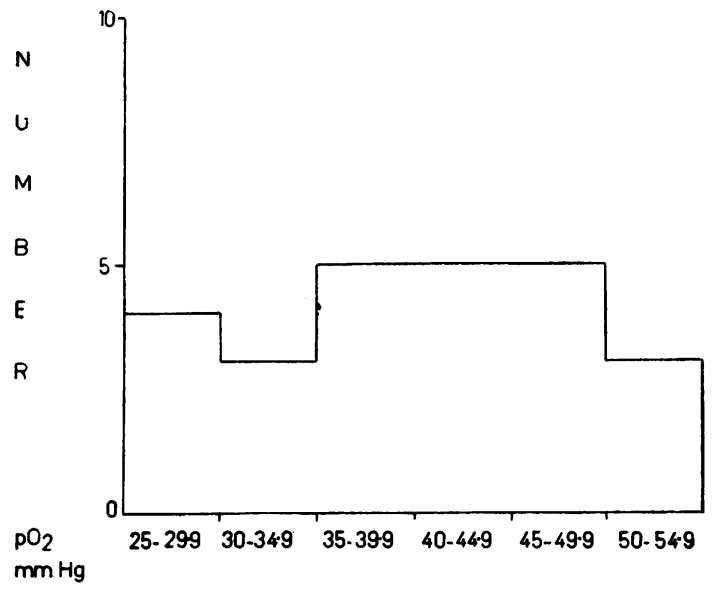

Fig. 3.-Distribution of the oxygen tension in the intervillous blood of the placenta. 
According to Walker and Turnbull (1953) advancing gestation time especially after 40 weeks causes a decrease in the oxygen saturation in the cord blood. These results have been confirmed by MacKay (1957), whereas no such change has been observed by MacKinney et al. (1955), BancroftLivingston and Neill (1957) or Rooth and Sjöstedt (1957). Recently Turnbull and Baird (1957) and Walker and Turnbull (1959) have stated that this decrease only occurs in primigravidae.

In his series Wulf had nine cases of prolonged pregnancy and found the average $\mathrm{pO}_{2}$ in the vein to be 13.3 and in the arteries $9.4 \mathrm{~mm}$. $\mathrm{Hg}$. Since not less than five of these infants were asphyxiated at birth and needed artificial respiration it cannot be concluded from Wulf's data that prolonged pregnancy per se decreases the $\mathrm{pO}_{2}$ of the cord blood. In our series of 113 normal infants 45 cases have a gestation time of 41 weeks or more and, as shown in Tables 1 and 2, the $\mathrm{pO}_{2}$ in the umbilical vein and arteries is about the same from the 38th to the 43rd week of pregnancy. The same is valid for primigravidae. Thus it is not possible to demonstrate any physiological change in the $\mathrm{pO}_{2}$ in the umbilical blood immediately before, during or after term.

Nearly all authors have found the arteriovenous difference to be $10-13 \mathrm{~mm}$. Hg (Table 1). Only Wulf has a bigger difference, $16 \mathrm{~mm}$. $\mathrm{Hg}$.

No direct measurement of the intervillous $\mathrm{pO}_{2}$ has been published, but our mean value, $40 \mathrm{~mm}$. $\mathrm{Hg}$, may be compared to that of Prystowsky (1957). Prystowsky measured the oxygen saturation and estimated the $\mathrm{pO}_{2}$ from an oxygen dissociation curve without giving any measurements of $p \mathrm{H}$. In eight cases he had a mean of $37.5 \mathrm{~mm}$. $\mathrm{Hg}$ with the range $24 \cdot 0-72 \cdot 0 \mathrm{~mm}$. Hg. Walker and Turnbull (1959) also measured the oxygen saturation in the intervillous blood and estimated the $\mathrm{pO}_{2}$ to be $36-40 \mathrm{~mm} . \mathrm{Hg}$. Beer et al.(1955) calculated the intervillous $\mathrm{pO}_{2}$ as $30.2 \mathrm{~mm}$. $\mathrm{Hg}$, basing their figures on their measurements of the cord blood and data on the maternal arterial blood. As their cord blood figures were much lower than ours, as already discussed, it is not surprising to find their figure for the intervillous blood lower than ours.

It seems therefore that the normal foetus gets its oxygen supply from the maternal side of the placenta at a tension of about $40 \mathrm{~mm}$. $\mathrm{Hg}$. It is not yet known whether the observed scatter of $\pm 13 \mathrm{~mm} . \mathrm{Hg}$ is due to individual variations in the mother or to fortuitous sampling near or distal to the arterial blood entering the intervillous space.

Given the data on the $\mathrm{pO}_{2}$ of the intervillous blood, umbilical vein and umbilical artery blood it is possible to calculate the mean drop in oxygen pressure between the maternal and foetal circulation, which is defined as the pressure drop between the intervillous space and the mean between the umbilical artery and umbilical vein. We thus find a value of $16 \mathrm{~mm}$. Hg. It should be remembered that in no instance have we measured the individual pressure drop and the figure given here is one based on average normal intervillous blood and average normal foetal blood. Prystowsky (1957), obtaining the cord blood one minute after obtaining the intervillous samples, has been able in three cases to estimate the pressure drop from measurements of the oxygen saturation and found 17.7, 18.3 and $20.4 \mathrm{~mm}$. $\mathrm{Hg}$, i.e. figures of the same order as in our measurements. When the mothers were given oxygen, Prystowsky (1959) found that the mean pressure drop increased to $37.5 \mathrm{~mm}$. Hg. Beer et al., who, as mentioned, have measured $\mathrm{pO}_{2}$ in the cord blood, made ingenious calculations of the intervillous space blood. If their figures are used in the same way to calculate the mean pressure drop it will be $14.4 \mathrm{~mm}$. Hg. From this it seems that the normal pressure drop is somewhere between 15 and $20 \mathrm{~mm}$. Hg. It is noteworthy that this is much higher than the corresponding drop in the alveoli, where it is of the order of a few $\mathrm{mm}$. $\mathrm{Hg}$. One reason for this, besides the obvious anatomical differences, is that when the blood is very hypoxic, as is that of the cord arteries, a long contact time is necessary for complete equilibration, and probably the time in question is too short in the placenta. It is extremely risky to estimate the pressure drop in the tissue between the maternal and foetal circulation in the placenta from the present figures, but at any rate it cannot be higher than the difference between the intervillous blood and the umbilical vein, i.e. $10 \mathrm{~mm}$. Hg. Probably the drop is lower.

\section{Summary}

The oxygen tension in the umbilical vein at the time of delivery in normal cases ranges from 6 to $46 \mathrm{~mm}$. $\mathrm{Hg}$ with a mean of $29.3 \mathrm{~mm}$. $\mathrm{Hg}$. In the umbilical arteries the range is from 6 to $32 \mathrm{~mm}$. $\mathrm{Hg}$ with a mean of $18.3 \mathrm{~mm}$. $\mathrm{Hg}$.

The mean values in a group of slightly asphyxiated infants in both arteries and vein is a few $\mathrm{mm}$. $\mathrm{Hg}$ lower.

The mean value in the umbilical vein is the same in the normal group as in a group of infants with meconium stained amniotic fluid, but the mean value in the arteries in this group is about the same as in the asphyxiated group. 
In the intervillous space the mean $\mathrm{pO}_{2}$ in 25 cases is $39.9 \mathrm{~mm}$. $\mathrm{Hg}$.

This study was supported by grants from the Association for the Aid of Crippled Children, New York, U.S.A., the Swedish Medical Research Council, Uppsala, and Svenska Nationalföreningen mot tuberkulos och andra folksjukdomar, Stockholm, Sweden.

\section{REFERENCES}

Bancroft-Livingston, G. and Neill, D. W. (1957). Studies in prolonged pregnancy. J. Obstet. Gynaec. Brit. Emp., 64, 498.

Barron, D. (1959). In Oxygen Supply to the Human Foetus, ed. J. Walker and A. C. Turnbull. Symposium organized by Council for International Organizations of Medical Sciences and Josiah Macy, Jr., Foundation. Blackwell, Oxford.

Bartels, H. (1951). Potentiometrische Bestimmung des Sauerstoffdruckes im Vollblut mit der Quecksilbertropfelektrode. Theorie und Versuche. Pfiügers. Arch. ges. Physiol., 254, 107.

Beer, R., Bartels, H. and Raczkowski, H.-A. (1955). Die Sauerstoffdissoziationskurve des fetalen Blutes und der Gasaustausch in der menschlichen placenta. Ibid., 260, 306 .

Haselhorst, G. and Stromberger, K. (1931). Über den Gasgehal des Nabelschnurblutes vor und nach der Geburt des Kindes und über den Gasaustausch in der Plazenta. Z. Geburtsh. Gynäk. $100,48$.

MacKay, R. B. (1957). Observations on the oxygenation of the foetus in normal and abnormal pregnancy. J. Obstet. Gvnaec. Brit. Emp., 64, 185.
MacKinney, L. G., Ehrlich, F., Goldberg, I. D. and Cantwell, K. T. (1955). Cord blood gas analyses with special reference to fetal maturity and placental function. Proc. Soc. ped. Res., 90, 520.

Norman, O. (1953). Placentography. Symposium III. Localization of the placenta by means of arteriography and auscultation. Brit. J. Radiol., 26, 393 .

Prystowsky, H. (1957). Fetal blood studies. VII. The oxygen pressure gradient between the maternal and fetal bloods of the human in normal and abnormal pregnancy. Johns Hopk. Hosp. Bull., 101, 48.

- (1959). Fetal blood studies. XI. The effect of prophylactic oxygen on the oxygen pressure gradient between the maternal and fetal bloods of the human in normal and abnormal pregnancy. Amer. J. Obstet. Gynec., 78, 483.

Rooth, G. and Sjöstedt, S. (1955). Oxygen saturation in the umbilical cord. Acta obstet. gynec. scand., 34, 442.

- (1957). Oxygen saturation in the umbilical vessels of the human

36, 374 . in whole blood with the Clark cell. Clin. Sci., 18, 379 .

Sjöstedt, S., Rooth, G. and Caligara, F. (1960). The oxygen tension in the cord blood after normal delivery. Acta obstet. gynec. scand., 39, 34.

Turnbull, E. P. N. and Baird, D. (1957). Maternal age and foetal oxygenation. Brit. med. J., 2, 1021 .

Walker, J. and Turnbuli, A. C. (1959). Oxygen Supply to the Human Foetus. Symposium organized by Council for International Organizations for Medical Sciences and J. Macy, Jr., Foundation. Blackwell, Oxford.

and Turnbull, E. P. N. (1953). Haemoglobin and red cells in the human foetus. Lancet, 2, 312.

Wulf, H. (1958). Blutgaswerte und Neugeborenatmung. Klin. Wschr., 36, 234. 